${ }^{3}$ Lettin AWF. Total hip replacement. Br f Hosp Med 1980;24:328-45.

${ }^{4} \mathrm{McKee}$ GK, Chen SC. The statistics of the McKee-Farrar method of total hip replacement. Clin Orthop 1973 ;95:26-33.

${ }^{5}$ Dobbs HS. Survivorship of total hip replacements. 7 Bone foint Surg $1980 ; 62 B: 168-73$

${ }^{6}$ Ring PA. Total replacement of the hip joint. Clin Orthop 1973;95:34-7.

7 Salvati EA, Wilson PD, Jolley MN, Vakili F, Aglietti P, Brown GC. A ten-year follow-up study of our first one hundred consecutive Charnley total hip replacements. $\mathcal{F}$ Bone foint Surg 1981;63A:753-67.

${ }^{8}$ Beckenbaugh RD, Ilstrup DM. Total hip arthroplasty. A review of three hundred and thirty-three cases with long follow-up. F Bone foint Surg 1978;60A :306-13.

${ }^{9}$ Mueller ME. Ten to twelve year follow-up of total hip replacement. Proceedings of the annual meeting of the International Hip Society, 1980. (In press.)

${ }^{10}$ Amstutz HC, Markolf KL, McNeice GM, Gruen TA. Loosening of total hip components: cause and prevention. In: Evarts $\mathrm{CM}$, ed. The hip. Proceedings of the fourth open scientific meeting of the Hip Society, 1976. Saint Louis: C V Mosby Co, 1976:102-16.

11 Lee AJC, Ling RSM, Vangala SS, Buck S. Some clinically relevant variables affecting the mechanical behaviour of bone cement. $\mathcal{F}$ Bone foint Surg 1978;60B:137.

${ }^{12}$ Chandler HP, Reineck FT, Wixson RL. A five year review of total hip replacements in patients under the age of 30-with emphasis on loosening. Orthopedic Transactions 1979;3:303.

\section{Specific heart disease in diabetes mellitus}

Heart disease is a major cause of death in patients with diabetes mellitus, ${ }^{12}$ and the risk of atherosclerotic coronary artery disease is substantially increased in patients with both overt diabetes and asymptomatic hyperglycaemia. ${ }^{2} 3$ Recent epidemiological evidence from the Framingham study ${ }^{4}$ has confirmed the increased incidence of angina and myocardial infarction, especially in women, but has also suggested that the frequency of congestive heart failure is greater than that predicted from atherosclerotic risk factors. While most diabetics have more-than-average atherosclerosis, indistinguishable from that in non-diabetics, ${ }^{5}$ two separate theories have been advanced to explain the increased risk of cardiovascular disease: the presence of atherosclerosis or small vessel disease.

Necropsy material from diabetics dying of unexplained congestive heart failure ${ }^{6}$ or myocardial infarction ${ }^{7}$ and angiographic studies of diabetics with chronic renal ${ }^{8}$ or heart failure ${ }^{9}$ have shown severe and widespread occlusive atherosclerosis of the coronary arteries. Other studies suggest, however, that heart failure may be attributed to small vessel disease of the coronary circulation-analogous to that found in the retina and kidney-with relatively normal coronary arteries at necropsy $y^{10}{ }^{11}$ or on angiography. ${ }^{1213}$ Histological examination of the heart in diabetics shows abnormalities of the small vessels with intimal proliferation and thickened walls, ${ }^{10-12} 14$ perivascular and interstitial fibrosis, ${ }^{14}$ and accumulation of glycoproteins and lipids. ${ }^{13}$ Thickening of the capillary basement membrane, an ultrastructural hallmark of diabetes, has been found in a myocardium. ${ }^{15} \mathrm{~A}$ recent elegant study by Factor and co-workers ${ }^{16}$ showed capillary microaneurysms in necropsy specimens injected with silicone rubber, emphasising that diabetic microangiography is widespread and that many tissues may be affected.

Non-invasive methods of assessing left ventricular function have confirmed that it is frequently impaired in young, ${ }^{17}$ asymptomatic diabetics, ${ }^{18}$ in maturity onset diabetics, ${ }^{19}$ and in those with retinopathy and nephropathy. ${ }^{20}{ }^{21} \mathrm{~A}$ relation appears to exist between the extent of clinical microangiography and the degree of impairment of left ventricular function ${ }^{22}$; diabetics with proliferative retinopathy and nephropathy have the most severe ventricular dysfunction. In diabetics the left ventricle is not dilated or hypertrophied, ${ }^{23}$ and abnormalities of function are predominantly in diastole, with delayed opening of the mitral valve and prolongation of the isovolumic relaxation time. Reduced ejection and abnormal systolic time intervals are probably late events. ${ }^{19-22}$ These diastolic abnormalities may be differentiated from those found in occlusive coronary artery disease, where incoordinate ventricular relaxation is the principal feature. ${ }^{23}$

Furthermore, in addition to large and small vessel disease, diabetics have other reasons for their impaired left ventricular function: tissue perfusion and oxygenation are compromised by platelet and coagulation abnormalities, ${ }^{24}$ increased blood viscosity, ${ }^{25}$ and reduced erythrocyte deformability. ${ }^{26}$

What are the prospects for prevention and treatment? Non-specific measures directed at reducing the risk of microangiopathy, such as close control of blood glucose, ${ }^{27}$ the vigorous treatment of hypertension ${ }^{28}$ (which may further impair left ventricular function directly ${ }^{23}$ ), and discouragement of cigarette smoking ${ }^{29}$ are unproved but may help. Agents which modify the abnormal rheological features in diabetes are also being evaluated. Drugs and dietary manoeuvres that lower plasma lipid concentrations would be unlikely to influence the microvascular component of the disease, and in the absence of angina due to coronary artery disease coronary artery bypass grafting has no value in impaired left ventricular function. No specific treatment exists, indeed, for severe left ventricular disease. Isolated reports that continuous subcutaneous infusion of insulin may reverse or prevent the progression of retinopathy $^{30}$ suggest that the technique may have a similar protective effect on the small coronary arteries.

Whether specific heart disease due to diabetic microangiopathy occurs in addition to or independently of coronary artery atherosclerosis remains uncertain, but left ventricular function is frequently found to be impaired in the absence of angina or myocardial infarction. Simple non-invasive techniques for detecting abnormal left ventricular function may help differentiate those diabetics who are at low risk-and may look forward to a long period free from vascular complicationsfrom those at high risk while clinically free from vascular disease.

L M SHAPIRO

Registrar in Cardiology,

Royal Postgraduate Medical School,

London $\mathrm{W} 12$ OHS

' Liebow IM, Hellerstein HK. Cardiac complications of diabetes mellitus. Am $\mathcal{F}$ Med 1949;7:660-70.

${ }^{2}$ West KM. Epidemiology of diabetes and its vascular lesions. New York: Elsevier, 1978

${ }^{3}$ Stamler R, Stamler J. Asymptomatic hyperglycemia and coronary heart disease. A series of papers by the international collaborative group based on studies in fifteen populations. 7 Chronic Dis 1979;32:683-91.

4 Kannel WB, McGee DL. Diabetes and cardiovascular disease. The Framingham study. $\mathcal{F} A M A 1979 ; 241: 2035-8$.

${ }^{5}$ Robertson WB, Strong JP. Atherosclerosis in persons with hypertension and diabetes mellitus. In: McGill HC Jr, ed. The geographic pathology of atherosclerosis. Baltimore: Williams and Wilkins, 1968:78-91.

${ }^{6}$ Boucher CA, Fallon JT, Johnson RA, Yurchak PM. Cardiomyopathic syndrome caused by coronary artery disease. III : Prospective clinicopathological study of its prevalence among patients with clinically unexplained chronic heart failure. Br Heart $\mathcal{F}$ 1979;41:613-20.

${ }^{1}$ Crall FV, Roberts WC. The extramural and intramural coronary arteries in juvenile diabetes mellitus. Analysis of nine necropsy patients aged 19 to 38 years with onset of diabetes before age 15 years. Am $\mathcal{J}$ Med $1978 ; 64: 221-30$.

${ }^{8}$ Weinrauch L, D'Elia JA, Healy RW, Gleason RE, Christlieb AR, Leland OS. Asymptomatic coronary artery disease: angiographic assessment of diabetics evaluated for renal transplantation. Circulation 1978;58:1184-90. 
${ }^{9}$ Dash H, Johnson RA, Dinsmore RE, Francis CK, Harthorne JW. Cardiomyopathic syndrome due to coronary artery disease. II: Increased prevalence in patients with diabetes mellitus: a matched pair analysis. Br Heart f $1977 ; 39: 740-7$.

'" Rubler S, Dlugash J, Yuceoglu YZ, Kumral T, Branwood AW, Grishman. A. New type of cardiomyopathy associated with diabetic glomerulosclerosis. Am $\mathcal{F}$ Cardiol 1972;30:595-602.

"Hamby RI, Zoneraich S, Sherman L. Diabetic cardiomyopathy. FAMA $1974 ; 229: 1749-54$

12 Pearce MB, Bulloch RT, Kizziar JC. Myocardial small vessel disease in patients with diabetes mellitus. Circulation 1973;48, suppl IV:6.

${ }^{13}$ Regan TJ, Lyons MM, Ahmed SS, et al. Evidence for cardiomyopathy in familial diabetes mellitus. $\mathcal{F}$ Clin Invest 1977;60:885-99.

${ }^{14}$ Ledet T. Diabetic cardiopathy. Quantitative histological studies of the heart amongst young juvenile diabetics. Acta Pathol Microbiol Scand $(A)$ $1976 ; 84: 421-8$

${ }^{15}$ Fischer VW, Barner HB, Leskiw ML. Capillary basal laminar thickness in diabetic human myocardium. Diabetes 1979;28:713-9.

${ }^{16}$ Factor SM, Okun EM, Minase T. Capillary microaneurysms in human diabetic heart. $N$ Engl f Med 1980;302:384-8.

${ }^{17}$ Rynkiewicz A, Semetkowska-Jurkiewicz E, Wyrzykowski B. Systolic and diastolic time intervals in young diabetics. Br Heart $\mathcal{F} 1980 ; 44: 280-3$.

18 Ahmed SS, Jaferi GA, Narang RM, Regan TJ. Preclinical abnormality of left ventricular function in diabetes mellitus. Am Heart 7 1975;89: $153-8$

19 Shapiro LM, Leatherdale BA, Coyne ME, Fletcher RF, Mackinnon J Prospective study of heart disease in untreated maturity onset diabetics. Br Heart 7 1980;44:342-8.

${ }^{20}$ Seneviratne BIB. Diabetic cardiomyopathy: the preclinical phase. Br Med F 1977; i:1444-6.

${ }^{21}$ Sanderson JE, Brown DJ, Rivellese A, Kohner E. Diabetic cardiomyopathy? An echocardiographic study of young diabetics. $\mathrm{Br} M e d f$ $1978 ; \mathrm{i}: 404-7$.

22 Shapiro LM, Leatherdale BA, Mackinnon J, Fletcher RF. Left ventricular function in diabetes mellitus. II : Relation between clinical features and left ventricular function. Br Heart 7 1981;45:129-32.

${ }^{23}$ Shapiro LM, Howat AP, Calter MM. Left ventricular function in diabetes mellitus. I: Methodology, and prevalence and spectrum of abnormalities. Br Heart $71981 ; 45: 122-8$.

${ }^{24}$ Fuller JH, Keen H, Jarrett RJ, et al. Haemostatic variables associated with diabetes and its complications. Br Med $\mathcal{f}$ 1979;ii:964-6.

${ }^{25}$ Barnes AJ, Locke P, Scudder PR, Dormandy TL, Dormandy JA, Slack J. Is hyperviscosity a treatable component of diabetic microcirculatory disease? Lancet 1977; ii:789-91.

${ }^{26}$ McMillan DE, Utterback NG, La Puma J. Reduced erythrocyte deformability in diabetes. Diabetes 1978;27:895-901.

27 Tchobroutsky G. Relation of diabetic control to development of microvascular complications. Diabetologia 1978;15:143-52.

${ }^{28}$ Knowler WC, Bennett PH, Ballentine EJ. Increased incidence of diabetic retinopathy with elevated blood pressure. N Englf Med 1980;302:64550.

${ }^{29}$ Paetkau ME, Boyd TAS, Winship B, Grace M. Cigarette smoking and diabetic retinopathy. Diabetes $1977 ; 26: 46-9$.

${ }^{30}$ Pickup JC, Keen H, Viberti GC, et al. Continuous subcutaneous insulin infusion in the treatment of diabetes mellitus. Diabetes Care 1980;3: 290-300.

\section{Motor neuron(e) disease}

Even allowing for loss of the " $\mathrm{e}$ " in translation across the ocean, the apparently simple concept of Motor Neurone Disease is far from universally accepted within the constellation of motor neurone diseases.

We may without trepidation let "motor neurone diseases" refer to all disorders characterised primarily by progressive weakness attributed to lesions of the anterior horn cell, whether or not any other parts of the neuraxis are affected. The major groupings included in this definition are the heredofamilial spinal muscular atrophies, with their own subtypes both eponymal and numerical, and motor neurone disease; lead or mercury intoxication contributes small numbers.

Here I shall use motor neurone disease as a generic entity. Its components are, firstly, amyotrophic lateral sclerosis for the combination of lesions of the anterior horn cells and pyramidal tract; secondly, progressive myelopathic (spinal) muscular atrophy when lesions are limited to the anterior horn below the foramen magnum; and, thirdly, progressive bulbar palsy for anterior horn affections of the brain stem. A patient with both progressive bulbar palsy and progressive myelopathic muscular atrophy would arbitrarily be classified as progressive bulbar palsy. And it is in this context that most European workers have, at least until recently, used motor neurone disease. Nevertheless, in the colonies in particular there are still some rebels who prefer amyotrophic lateral sclerosis as the generic term regardless of the sign of Babinski. But further to confound the question there is one European centre which seems to employ motor neurone disease as precisely equivalent to Charcot's disease of upper and lower motor neurone.

Appeal to the International Statistical Classification of Diseases, Injuries, and Causes of Death helps not at all. The new (9th) revision, in use since 1979, puts motor neurone disease and all its subtypes into one fourth-digit code under a three-digit rubric for "Anterior horn cell disease." Earlier editions were more discriminating and more variable. Nevertheless, even accepting motor neurone disease $=$ amyotrophic lateral sclerosis + progressive bulbar palsy + progressive myelopathic muscular atrophy does not solve our problems. There is "lytico," né "Guamanian amyotrophic lateral sclerosis," or "the Marianas Islands form of amyotrophic lateral sclerosis," or "the Western Pacific form of amyotrophic lateral sclerosis." First described for Chamorro natives of the island of Guam, the entity clinically and-initially-pathologically appeared identical with sporadic motor neurone disease. It is known to affect natives of Rota and Saipan (thus "Marianas"), and there are also foci of the identical disease within the Kii peninsula of south-eastern Honshu, Japan-plus another focus, without pathological proof, in certain villages of West New Guinea (thus "Western Pacific"). In these areas its occurrence is 20 to 50 times as common as is sporadic motor neurone disease. But more than frequency distinguishes this disorder. In the same places, and even in the same patients, there is another highly prevalent illness called the Parkinson-dementia complex, with a unique pathological character later discovered to be present even in those with only the amyotrophic lateral sclerosis syndrome. ${ }^{1-3}$ Most recently there may be emerging a "Madras amyotrophic lateral sclerosis," a sporadic disorder which adds sensorineural deafness to the clinical constellation of slowly progressive motor neurone disease. ${ }^{4}$ And large clinic series in the Occident may include perhaps $10 \%$ or fewer in whom motor neurone disease is inherited as an autosomal dominant trait. ${ }^{5}$

Nevertheless, the great bulk of the patients we see with motor neurone disease are of unknown origin and implacable progression, unaltered by treatment. Epidemiologically, ${ }^{6}$ this "true" motor neurone disease seems to be distributed uniformly about the world. Death rates within and among countries are for the most part between one and 1.5 per 100000 population a year. Almost all deaths are now attributed to amyotrophic lateral sclerosis. There is consistent male excess at 1.5 to 1 . In the United States there is also white:non-white differences of about 1.6:1. The age-specific rates rise from almost nil near age 50 to a sharp maximum at age 70 . This configuration holds for all lands and both sexes and colours.

Average annual incidence rates for motor neurone disease or amyotrophic lateral sclerosis are also mostly about one to 1.5 per 100000 population; point prevalence rates range from one to seven per 100000 , but the more complete studies suggest a prevalence of some five per 100000 . Age specific incidence 